\title{
O LABIRINTO NA TRADIÇÃO CLÁSSICA
}

\author{
José Ribeiro Ferreira *
}

\author{
Sozinha caminhei no labirinto
}

Aproximei meu rosto do silêncio e da treva Para buscar a luz de um dia limpo

Sophia de Mello Breyner Andresen

\section{O MITO}

Conta a lenda bem conhecida que Minos, rei de Cnossos, se recusou a sacrificar a Poséidon um touro branco de bela estampa e que o deus, como castigo ${ }^{1}$, fez suscitar na esposa, Pasífae, um amor monstruoso por esse touro. Para satisfazer o desejo incontrolável, a rainha pede a Dédalo, o engenhoso arquitecto e artista, que lhe modelasse uma forma taurina, onde ela se introduziu. Da união contra-natura, nasce uma criatura híbrida, com cabeça de touro e corpo de homem, cujo nome pessoal seria Astério, mas aparece geralmente designado como Minotauro e por esse nome é conhecido².

Então Minos encarrega Dédalo de construir um edifício especial, onde esse ser fosse encerrado - o Labirinto, uma construção de plano tão complicado que dele ninguém conseguia sair, uma vez lá entrado. Em consequência da morte do filho Androgeu, o rei Minos empreende uma expedição punitiva contra a Grécia continental e, vitorioso, obriga os Atenienses ao envio regular de sete rapazes e sete donzelas para servirem de alimento ao Minotauro. Durou o doloroso tributo, até que Teseu, filho de Egeu, rei de Atenas, na terceira vez do envio dos jovens, se oferece para integrar o grupo e, com a ajuda de Ariadne, filha de Minos, consegue matar o Minotauro e depois sair do Labirinto, seguindo o fio que a jovem apaixonada lhe aconselhara a estender.

Eliminado o monstro, Teseu parte de Creta com Ariadne que depois abandona na ilha de Naxos - que primitivamente tinha o nome de Dia - , onde Dioniso a encontra, a desposa e a leva para o Olimpo.

* Faculdade de Letras da Universidade de Coimbra; Faculdade de Letras do Pólo de Viseu da Universidade Católica Portuguesa. 
Entretanto, cansado da sua longa permanência forçada no palácio de Minos, Dédalo planeia fugir com o filho Ícaro. Constrói para os dois asas de penas de diferentes tamanhos, ligadas com linho e cera. Ao abandonarem o palácio, o filho, entusiasmado com a sua capacidade de voar, não teve em conta os conselhos do pai e aproximou-se do sol. A eterna ânsia de o homem se superar e de transpor os limites que o confinam. A cera das asas derrete-se e precipita-o no mar que desde então toma o seu nome. Assim é castigado pelo seu pecado de desmedida insolência e, por outro lado, se explica etiologicamente um nome geográfico.

\section{TESTEMUNHOS DOS POEMAS HOMÉRICOS}

É possível que esta tradição encubra, alterados, factos históricos e reais. Muitos destes nomes já se encontram nos Poemas Homéricos, os primeiros documentos literários da literatura grega que, embora compostos no século VIII a. C., se baseiam na técnica de improvisação oral e transmitem elementos de vários séculos antes, provindos em grande parte desde os tempos micénicos ${ }^{3}$. Na Ilíada, Minos e Radamento são filhos de Zeus e de Europa (14. 321-322) e em Tróia, entre os chefes aqueus que combatem sob o comando de Agamémnon (13. 402 sqq.), encontra-se Idomeneu, rei de Creta, que se vangloria de ser neto de Minos, e portanto descendente de Zeus (vv. 449-453). Ariadne e Dédalo surgem no mesmo poema, na descrição do Escudo de Aquiles, associados a Cnossos, quando se compara a dança cinzelada por Hefestos (18. 591-592)

\section{à que outrora, na imensa Cnossos,}

Dédalo organizou para Ariadna de belas tranças. ${ }^{4}$

Curiosamente Plutarco, Teseu 21. 1 fala de uma dança, executada por Teseu, em movimentos alternados e circulares que procuravam imitar as diversas voltas do labirinto.

Na Odisseia, Ulisses encontra Minos no Hades com o encargo de aplicar a justiça entre os mortos (11. 568-571) e mais tarde — em passo aliás discutível, por nomear os Dórios -, ao ser interrogado por Penélope sobre a sua identidade, inventa uma história fictícia, dizendo-se natural da formosa e feraz Creta, situada no meio do mar cor de vinho, irmão de Idomeneu e descendente de Minos que governara aquela ilha (19. 172-190).

Deixei para o fim um passo da Odisseia que tem significativa importância para o tema em análise, mas infelizmente já tem sido considerado uma interpo- 
lação ática posterior ${ }^{5}$. Ulisses na sua ida ao Hades encontra, entre as mulheres condenadas, Fedra e Ariadne que tinham sido esposas de Teseu (11. 321-325). Conta ele:

Vi Fedra, Prócris e a formosa Ariadne, filha de Minos de pensamentos funestos, que Teseu um dia trouxe de Creta para a cidadela da sagrada Atenas.

Não chegou porém a desfrutar dela. Antes, causou-lhe a morte Ártemis em Dia, rodeada pelo mar, por denúncia de Dioniso.

Embora aqui se não diga expressamente, estamos com certeza na presença de uma referência ao regresso do herói da luta vitoriosa com o Minotauro, na companhia de Ariadne. Disso é um indicativo o epíteto oloóphronos «de pensamentos funestos» aplicado a Minos e o facto de ser dada apenas a história de Ariadne naturalmente como uma consequência da ajuda dada a Teseu em Creta. $O$ passo explicita ainda que a separação de Teseu e da filha de Minos em Naxos se deveu à morte causada por Ártemis: seria a primeira das várias versões antigas relativas ao tema. A mais conhecida, que suplantou a referida no passo, é a do seu abandono pelo herói durante o sono, quer pelo facto de ele gostar de outra mulher, quer por ter sido incitado a tal por Atena para permitir a entrada em cena de Dioniso (Plutarco, Teseu 20) ${ }^{6}$.

Se o referido passo da Odisseia é autêntico, estaríamos perante a primeira alusão, na literatura grega, ao confronto de Teseu com o Minotauro e à ajuda que, na empresa, recebeu de Ariadne. E ela é tanto mais significativa e importante, quanto os Poemas Homéricos, compostos de acordo com a técnica da improvisação oral, como vimos, se reportam a acontecimentos dos tempos micénicos. Um dado a ter em conta e que merece ser confrontado com as informações das tabuinhas do Linear B - nome por que, como é sabido, é designado o silabário micénico. Ora, significativamente, essas tabuinhas parecem confirmar os nomes de Cnossos (Konoso), Amnisos (Aminiso, povoação próxima e a norte de Cnossos), Phaistos (Paito), Labyrinthos (dapuritojo), Teseu, Daidaléion. O nome Teseu das tabuinhas do Linear B (de Pilos e datáveis de cerca de 1200 a.C.) é dado a um indivíduo que era proprietário de terras. Quem sabe se já em consequência da repercussão da lenda de Teseu?

Embora, como observa Walter Burkert, não haja nas tabuinhas indícios do significado exacto de Daidaléion, não deixam de ser elucidativos os nomes dos palácios e sobretudo a especificação do Labirinto, tanto mais que o termo vai desaparecer e, até ao século $\mathrm{V}$ a. C., não volta a surgir na literatura grega. 


\section{RELAÇÃO POSSÍVEL COM O PALÁCIO DE CNOSSOS}

Nos inícios do nosso século, Evans procede a escavações em Cnossos e descobre um complexo edifício (fig. 1) que, contra a sua expectativa, apresentava uma estrutura arquitectónica diferente dos que Schliemann e Dörpfeld haviam revelado em Micenas e Tirinto: um emaranhado de compartimentos dispostos, irregularmente, em volta de um pátio central. Essa descoberta começou a desvendar ao mundo de então uma nova cultura que atinge o seu período áureo do Minóico Médio I ao Minóico Recente I, ou seja entre c. 2000 e 1500 a. C. Era uma cultura requintada e evoluída, que já conhecia a escrita — Linear A, ainda não decifrada —, que construiu grandes palácios, de estrutura complexa e com características colunas de menor espessura na base, ornados com belos frescos nas paredes e providos de sistemas de iluminação e de esgotos. Era a manifestação de um povo que se distinguiu na escultura em relevo e no tratamento dos animais, na finura e minúcia do trabalho do ouro e das gemas; que fabricou uma rica cerâmica, toda ela preenchida por motivos marítimos e vegetais.

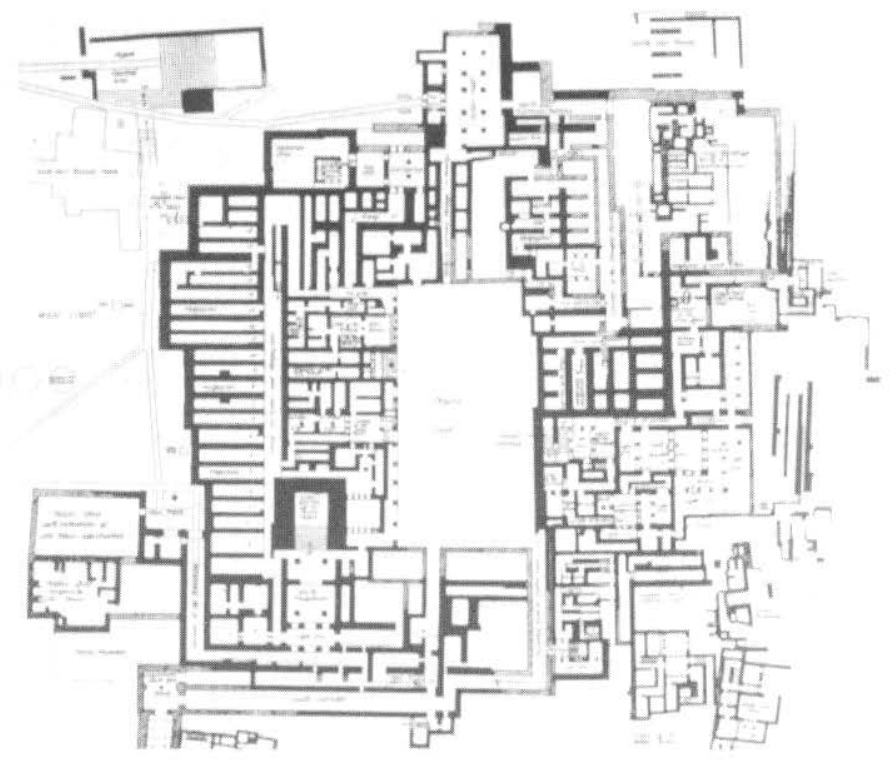

Fig. I - Planta do Palácio de Cnossos

Segundo Evans, as ruínas do complexo edifício de Cnossos que acabara de descobrir pertenciam a um palácio real, que era ao mesmo tempo um centro administrativo. Essa interpretação tem sido defendida e apoiada pelos melhores especialistas: caso de S. Hood e N. Platon que dirigiu as escavações no palácio de 
Que se tratava de um palácio, não é porém uma identificação unanimemente aceite: por exemplo, Wunderlich considera-o um edifício funerário, um palácio dos mortos $^{7}$, como a complexa construção egípcia de Hawara que os autores antigos apelidavam Labirinto do Egipto (Heródoto 2. 148; Diodoro Sículo 1. 66. 1-6; Estrabão 17. 1-37; Plínio 36. 13; Pompónio Mela 1. 9).

Recentemente Castleden tentou demonstrar que, em vez de um palácio, estaríamos na presença de um grandioso templo, onde se prestava culto a numerosos deuses da religião minóica. Assim a autoridade suprema não seria um rei, mas as sacerdotisas. É certo que tal interpretação se adaptaria à designação Potinija dapuritojo - «A Senhora do Labirinto» - , que surge nas tabuinhas do Linear B, e encontraria, de certo modo, paralelo em um templo da capital do Império Hitita, Hattusa, que apresenta uma planta complexa e assimétrica, a que também é costume dar o nome de Labirinto. E essa aproximação impor-se-ia tanto mais, quanto a bipene e os chifres de consagração, frequentes em Cnossos, parecem ligar-se a uma tradição anatólica.

Mas na conferência «O Palácio, do Mundo Minóico ao Helénico: Mito e realidade», proferida no IV Curso de Verão de História da Arte O Palácio: história, símbolo, forma, vivência (1992), a Professora Doutora Maria Helena da Rocha Pereira mostrou que, além de existir uma independência da arquitectura de Creta em relação a modelos orientais, a interpretação de Castleden - que aliás não é inteiramente nova - apoia-se quase só em conjecturas, possíveis pela ausência de dados concretos, e contraria a tese tradicional de que os Minóicos não possuíam templos. Faziam as suas vezes os palácios e grutas ${ }^{8}$.

Em qualquer dos casos, quer se trate de templo, quer de palácio, estaríamos perante um edifício de planta complexa que passou à posteridade com o nome de labirinto, onde vivia o Minotauro. E labirinto, como vimos, é precisamente um termo que ocorre nas tabuinhas do Linear B. A identificação da complexa estrutura descoberta por Evans com o lendário palácio de Minos é tendência que aliás não faz mais do que seguir a tradição que aí o colocava desde os primórdios da cultura grega. Convém ter em conta que os palácios posteriormente escavados em Creta, na sua disposição geral, apresentam semelhanças com o de Cnossos: caso de Mália (fig. 2), de Festos, Zacros, Gúrnia ${ }^{9}$. O de Cnossos era, no entanto, o mais extenso e magnificente.

As ruínas que hoje se encontram visíveis em Cnossos são as do edifício destruído no século XIV a. C., portanto já da fase final, mas a sua estrutura não deve ser muito diferente do que o antecedeu, construído depois das destruições ocorridas em cerca de 1700 a.C. ${ }^{10}$.

Era um edifício quase quadrado, de cerca de cento e cinquenta metros de lado, com um amplo espaço aberto ao centro, de forma rectangular, a característica mais saliente dos palácios de Creta. Tinha quatro entradas, uma em cada lado: a do norte levava directamente ao pátio central que chegou até nós muito destruído. 
Como porém não devia ser muito diferente dos outros palácios, e o de Mália permite identificar um altar central (vide fig. 2), o mesmo aconteceria em Cnossos. Um indício de que era um lugar que servia para cerimónias rituais.

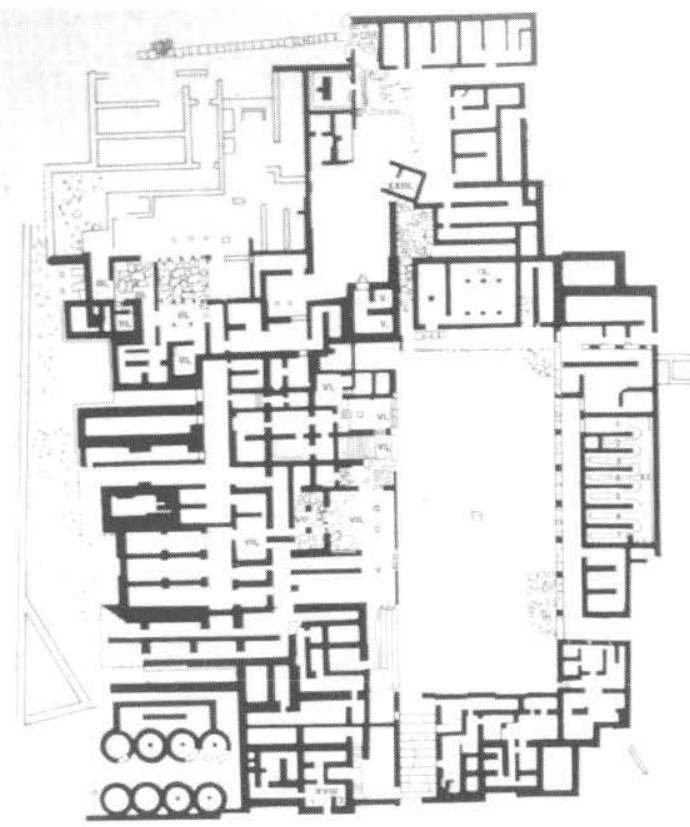

Fig. 2 - Planta do Palácio de Mália

O rés-do-chão da fachada oeste desse pátio central era ocupado por compartimentos com finalidades religiosas, dos quais se destaca a chamada sala do trono. Aí se sentavam os reis que eram ao mesmo tempo sacerdotes, ou mesmo divindades. Assim o palácio era santuário, casa dos governantes, local onde ficavam as repartições da administração — possivelmente no andar superior —, e onde se situavam os armazéns para recolher os impostos, todos em espécie ${ }^{11}$. Ricos frescos decoravam as paredes interiores. Monumentais lanços de escadas, quer a partir do pátio central, quer do exterior, davam acesso aos andares superiores. A encimar partes das fachadas e os pórticos das entradas, destacavam-se os chamados "chifres da consagração". É um aspecto curioso e um dado tanto mais significativo quanto parecem faltar nos outros palácios. Não pode deixar de relacionar-se com a importância que a representação do touro adquire na cultura minóica, em especial em Cnossos. Aí aparecem em figurações várias: em taças de ouro, em esculturas de cerâmica, em rítones em forma de cabeça de touro, vasos que possivelmente serviam para libações; sobretudo em representações do salto do touro, a mais conhecida das quais é o famoso fresco do Palácio de Cnossos «Jogo do Touro», de que a história de Teseu e do Minotauro pode bem ser um reflexo. 
S. Hood admite que Creta, durante o grande período da civilização minóica (de c. 2000 e 1500 a. C.), tenha sido uma espécie de federação de cidades, sem fronteiras, segundo um modelo da Mesopotâmia e da Síria. Cnossos gozaria, nessa federação, de qualquer espécie de hegemonia sobre as outras cidades, ou partilhá-la-ia com outros grandes centros ${ }^{12}$. Ora o touro é símbolo da força e poder da divindade, que entre os Minóicos estava estreitamente ligada ao rei. Sem esquecer a possibilidade de Minos não representar o nome de um rei, mas ser título de realeza, como o de faraó no Egipto ${ }^{13}$. Sendo assim justificar-se-ia que só em Cnossos apareçam os chifres da consagração.

É bem provável, por outro lado, que os Minóicos tivessem exercido domínio sobre o continente grego. É difícil acreditar, como nota S. Hood, que na época imperialista os reis de Creta - que nessa altura era uma ilha muito povoada não tivessem tentado expandir os seus domínios. Tudo indica que os governantes do continente foram tributários dos reis de Creta. Se não há dados seguros, a lenda de Teseu e dos jovens dos dois sexos destinados ao Minotauro é indício, ou até a afirmação de sujeição de Atenas ${ }^{14}$. Se o touro simboliza a força da divindade e vasos com forma de cabeça de touro são usados em libações -, se, na religião minóica, não é fácil distinguir o rei da divindade, o salto do touro não constituiria uma cerimónia de carácter religioso que se realizava em Cnossos, no palácio de Minos, o rei-sacerdote-divindade? Estamos no campo das hipóteses e nele continuaremos. Não estará o envio dos jovens atenienses relacionado com esse salto do touro, que não era propriamente um desporto e sem perigo? A libertação do tributo por Teseu, matando o Minotauro, não terá relação com a superação dos Minóicos pelos Micénios, verificada a partir do século XV a. C.? Tudo hipóteses para que não encontro respostas. Talvez a decifração da escrita minóica, o Linear A, possa um dia trazer alguma luz.

Outros dados e mais dúvidas. As escavações têm descoberto muitos machados de dois gumes ou bipenes - cujo nome antigo cretense teria sido, segundo Plutarco, labrys, uma palavra de origem lídia -, muitas delas no palácio de Cnossos, em ouro ou gravados nas paredes, pelo que este bem poderia ser conhecido também como a «Casa dos Machados de dois Gumes», ou Labirinto ${ }^{15}$.

Labirinto é um termo pré-grego que apresenta o sufixo nth, que encontramos em nomes pré-helénicos, como Corinto, Radamanto; Kretschmer deriva-o de labrys, a bipene que é um dos símbolos profusamente representados no edifício de Cnossos. Infelizmente a etimologia não é segura nem unanimemente aceite ${ }^{16}$.

\section{TRADIÇÃO LENDÁRIA RELATIVA AO MINOTAURO}

De qualquer modo, com centro em Cnossos e tendo por figuras centrais Teseu, Ariadne e o Minotauro, vai originar-se uma tradição lendária que não encontra 
grande aceitação na literatura, mas ganha considerável popularidade na arte figurativa, em especial na cerâmica.

\section{a) Na literatura}

Além dos Poemas Homéricos, a que já me referi, outras obras se referem à empresa de Teseu. Hesíodo, poeta que floresce por volta de 700 a. C., embora não fale no herói, nomeia Ariadne na Teogonia, se bem que em passo quase no final do poema que nem todos consideram autêntico: numa enumeração de uniões de deuses com mortais, lá se encontra também a da princesa com Dioniso, que na lenda se dá na sequência da sua separação de Teseu em Naxos (vv. 947-948):

E Dioniso, de dourados cabelos, a loura Ariadne, filha de Minos, tornou sua florescente esposa.

Em outro poema do Corpus que anda atribuído a Hesíodo, o Catálogo das mulheres, de que só nos restam fragmentos, encontramos alusão ao nascimento do Minotauro (fr. 145 Merkelbach-West), mas dá-o como filho de Minos, não do touro ${ }^{17}$ :

Ela, grávida de Minos, deu à luz um filho robusto, maravilha de se ver: igual ao do homem se estendia o corpo até aos pés, mas para cima erguia-se uma cabeça de touro.

Parece que, nos Cantos Cíprios, um poema do Ciclo Épico, da primeira metade do século VII a. C., da autoria de Estasino de Chipre, o tema de Teseu e Ariadne era narrado como uma espécie de paradigma de história de amor sem final feliz ${ }^{18}$.

Safo, cujo florescimento se situa nos inícios do século VI a. C., parece conhecer a história do Minotauro, das vítimas enviadas, de tempos a tempos, e da libertação por Teseu (fr. 206 Lobel-Page = 206 Campbell), embora do poema não subsista qualquer fragmento.

Simónides, nascido em meados do mesmo século, referia-se ao episódio da morte de Egeu, por causa do esquecimento da troca de vela no regresso de Teseu de Creta, como ficara combinado, para anunciar ao pai se a empresa tivera êxito ou não:

Uma vela purpúrea, tingida

na húmida flor de uma azinheira, frondosa. 
Embora o fragmento (fr. 550 Campbell = Plutarco, Teseu 17. 4) não refira a luta de Teseu com o Minotauro, ela está implícita. A tradição no entanto fala de vela branca, Simónides inova, dando-lhe uma outra cor.

Baquílides, no ditirambo 17 , de três tríades, composto entre 477 e 470 a.C. ${ }^{19}$, refere o episódio lendário em que Teseu censura Minos e este o desafia a provar que é filho de Poséidon, como afirma. Teseu e os outros jovens atenienses, tributo ao Minotauro, caminham para Creta, no barco de Minos que se encontra inflamado de desejo por Eribeia. Perante a censura do herói de se não saber dominar e a sua disposição em lutar para proteger a donzela, o rei de Cnossos, encolerizado, pede a Zeus um sinal que comprove a sua filiação divina e, atirando um anel ao mar, convida Teseu a mergulhar para comprovar que descende de Poséidon. Enquanto um relâmpago corta o céu, o herói lança-se ao mar, é recebido no palácio de Poséidon e de Anfitrite e depois reaparece junto do navio, revestido de vestes reais, perante a estupefacção de $\operatorname{Minos}^{20}$.

Eurípides - e com este tragediógrafo estamos na segunda metade do século $\mathrm{V}$ a. C. - trata o tema algumas vezes e a ele alude outras. No Héracles 1326-1328, Teseu dirige-se a Héracles, concede-lhe hospitalidade e promete-lhe os presentes que os cidadãos lhe ofereceram por ter salvado os sete rapazes e sete raparigas, ao matar o touro de Cnossos. Das peças perdidas, Cretenses talvez se relacionasse com o nascimento do Minotauro (frs. 471-472 $\mathrm{N}^{2}$ ) e Teseu parece ter dramatizado a morte do monstro e a fuga subsequente do herói (frs. 381-390 $\mathrm{N}^{2}$; POxy 27, $2461)^{21}$.

Em Platão, no Fédon 58a-b, há uma referência ao navio ateniense que anualmente vai a Delos em cumprimento da promessa feita no momento em que Teseu embarcou para Creta com os sete pares de rapazes e raparigas - repare-se na fórmula religiosa «sete pares». Este diálogo de Platão foi interpretado por Burger como um labirinto em que o Minotauro simbolizaria o receio da morte. Penso que sem razão e sem grande fundamento, como o mostrou Maria Teresa Schiappa de Azevedo em recensão na Humanitas ${ }^{22}$.

Podemos concluir que, até ao século V a. C., a morte do Minotauro por Teseu não é o centro nem adquire relevo em nenhuma obra literária. Apenas alusões, referências breves, fugidias. A lenda de Teseu está mesmo ausente de muitos autores gregos. Estranhamente esse herói é o grande ausente da literatura grega até essa data. Não o menciona Alceu; não há alusões a tal figura em Píndaro. E no que respeita à ida do herói ateniense a Creta, essa façanha só aparece sistematizada e ganha relevo em autores tardios (Plutarco, Diodoro Sículo, Estrabão) e em escritores romanos (Catulo, Ovídio).

Apesar disso, as referências e alusões apontadas mostram que, na época arcaica e clássica, as lendas relativas ao Minotauro e ao feito de Teseu estavam divulgadas. E de tal é um elucidativo exemplo a alusão do Fédon. 


\section{b) Na arte figurativa}

Mas é a arte figurativa, em especial a cerâmica, que mostra não ser o silêncio da literatura sinónimo de desconhecimento e falta de repercussão. O confronto de Teseu com o Minotauro é um tema muito tratado, com considerável incremento a partir de meados do século VI a. C., a ponto de se tornar um dos temas mais populares da iconografia grega, representado em vasos das mais diversas regiões: Corinto, Beócia, ilhas, Sicília, Itália, mas sobretudo a Ática ${ }^{23}$.

As mais antigas imagens, seguras, do Minotauro aparecem no Peloponeso em cinco placas de ouro, com relevos idênticos, provenientes de Corinto, que são datáveis de cerca de meados do século VII a. C. Mostram Teseu a lutar com o Minotauro, enquanto Ariadne assiste segurando um novelo de fio na mão direita $^{24}$. De data aproximada à dessas placas uma ânfora, de cerca de 670-660 a.C., representa a luta de Teseu com o Minotauro, Ariadne a observar e um novelo de fio aos pés do Minotauro ${ }^{25}$. Isto prova que os temas do combate de Teseu com o Minotauro e da ajuda de Ariadne ao herói estavam já bem estabelecidos por essa altura na tradição lendária e formavam os elementos mais antigos na arte figurativa ${ }^{26}$. A partir de meados do século VI a. C. já temos representações da luta de Teseu e o Minotauro, com a jovem a desenrolar o fio ${ }^{27}$. Ariadne a entregar ao herói um novelo de fio tornar-se-á um motivo popular na arte romana ${ }^{28}$.

No século V a. C. era considerável a popularidade do tema de Teseu a matar o Minotauro, popularidade que parece ter-se estendido para o século IV a. C. ${ }^{29}$ Era considerada a mais saliente façanha do herói, como mostra a taça de Londres E 84

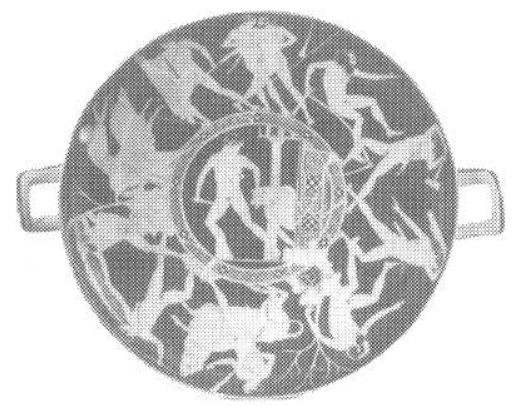

Fig. 3 - Taça de Londres E84, British Museum

(Fig. 3) e a de Harrow com o ciclo dos seus feitos: em uma e outra está em evidência no centro da taça, rodeada de várias outras.

Possivelmente a lenda de Teseu encontra a sua divulgação através de contos populares. E o facto de ser um herói essencialmente popular explicaria a sua não entrada na literatura da época arcaica, de base aristocrática, a não ser em alusões fugidias ou marginais. A sua divulgação parece estar relacionada com o nascimento da democracia. Escreve Alberto Barnabé que a lenda do Minotauro, que nas suas origens é a história do combate de um herói contra um monstro, se reinterpreta, nos fins do século VI e inícios do $\mathrm{V}$ a. C., como o modelo de herói civilizador que se livra do tirano, 
que era Minos, do mesmo modo que os Atenienses se haviam libertado dos tiranos, os Pisístratos, para dar origem a um novo regime democrático ${ }^{30}$. Tornou-se o herói da libertação e aparece a cada passo como modelo de bom governante.

A história do Minotauro tornou-se muito popular entre os Etruscos e daí passou para os Romanos que, no entanto, não se mostraram muito interessados em tratar o tema na arte figurativa, a não ser nos mosaicos ${ }^{31}$.

\section{O TEMA DO LABIRINTO}

Se a luta de Teseu com o Minotauro não é um tema frequente na literatura, o labirinto ainda o é menos. Mas este nem na literatura nem na arte. No entanto, ele encontra-se sempre implícito no mito de Teseu e do Minotauro e a ele associado.

A palavra, cuja possível origem já analisei, aparece nas tabuinhas do Linear B (séc. XIII a.C.), mas depois perdemos-lhe o rasto e só a voltamos a encontar, no século $\mathrm{V}$ a.C., em Heródoto, quando descreve o complexo edifício funerário, situado junto do lago Méris, com três mil compartimentos, como especifica o historiador (2. 148-149). Nessa descrição utiliza o termo labyrinthos por sete vezes.

Em Platão, no Eutidemo 291b, temos o emprego metafórico do termo. Sócrates está a falar com os discípulos sobre as artes e as ciências; a determinada altura, refere que, na sua busca, são como crianças atrás das calhandras: quando se julgavam a atingir a arte por excelência, «então, como se tivéssemos caído num labirinto, no momento em que pensamos estar no fim, encontramo-nos de novo, dada a volta, a bem dizer no começo da procura e tão pouco avançados como quando a iniciámos».

Mas a aplicação específica da palavra labirinto a designar o lugar de Cnossos em que vivia o Minotauro só aparece pela primeira vez nos autores gregos do período helenístico - naturalmente por mero acaso. Calímaco, no Hino a Delos, refere (vv. 300-315) que em Delos os coros e danças são constantes e não cessam as ofertas de coroas à sagrada e venerada imagem de Cípris, que outrora Teseu e os outros jovens consagraram, quando regressavam de Creta (vv. 310-313):

Ao fugir do monstro que solta mugidos, rebento feroz de Pasífae, e da recurva morada do turtuoso labirinto, senhora, em volta do teu altar e ao som da cítara, dançaram em círculo. Conduzia o coro Teseu.

Na arte figurativa também não é um motivo usual. Moedas de Creta do século V a.C. têm gravada, no anverso, a figura do Minotauro e, no reverso, a repre- 
sentação do labirinto ${ }^{32}$. Em alguns dos vasos que representam a luta de Teseu com o Minotauro, o labirinto aparece sugerido por diversos elementos: porta com gregas ou gregas combinadas com xadrês, estelas com desenhos vários e diversificados (gregas, ondas, riscos desencontrados). Dou como exemplo duas belas taças áticas: uma de c. 440-420 a.C., que se encontra no British Museum (vide fig. 3), e a taça pintada Aison, de cerca de 420 a. C., que pertence ao Museu Arqueológico de Madrid (fig. 4). Aí aparecem

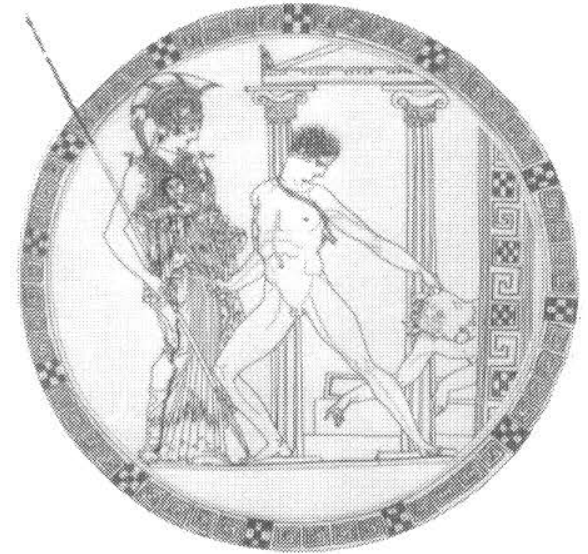

Fig. 4 - Taça de Aison

(Museu Arqueológico de Madrid) representados os diversos feitos de Teseu, com a morte do Minotauro em destaque ao centro. O herói arrasta o monstro morto de que apenas metade no exterior do labirinto. Deste só se encontra representada a porta entreaberta que, no entanto, apresenta gregas complexas e rectângulos em xadrez.

\section{A LIGAÇÃO DOS DOIS ELE- MENTOS DO MITO}

A descrição sistemática, de forma a unir o edifício de planta complexa construído por Dédalo, o tributo ao Minotauro, o feito de Teseu, a ajuda de Ariadne e o seu abandono em Naxos só nos aparece em autores gregos tardios e em autores romanos. Plutarco, na Vida de Teseu, dá evidentemente grande relevo a esse seu feito e já procura discutir as várias versões então existentes (15-23). Diodoro Sículo, ao mencionar o complexo monumento funerário egípcio a que já me referi, fala do labirinto de Creta, mas acrescenta que do edifício construído por Dédalo para o rei Minos nada restava na sua época (1.61).

Entre os autores romanos, destaco Catulo e Ovídio. O primeiro, num belo poema - a carme 64, conhecido como "As Bodas de Peleu e Tétis" —, descreve a colcha da cama nupcial, na qual estava representado o abandono de Ariadne por Teseu e se narra o cruel tributo, o feito do herói libertando os Atenienses da dolorosa obrigação, a ajuda de Ariadne, o seu abandono em Naxos e o consequente castigo do esquecimento da troca de velas. Não desenvolvo por escassez de tempo, mas não resisto a lembrar um pormenor curioso e muito feminino: Ariadne, quando vê o barco de Teseu afastar-se ao longe, corre para o mar em desespero, mas sem esquecer de levantar as delicadas vestes, para as águas as não

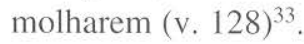

Ovídio trata o tema em duas obras: em Heroídes 10, foca o amor de Ariadne por Teseu que a levou a prestar-lhe ajuda. No livro oitavo das Metamorfoses 
narra a expedição de Minos ao continente, o nascimento do Minotauro e a consequente construção do Labirinto por Dédalo, que o rei mantinha cativo, a fuga do engenhoso arquicteto e do filho e a fatal imprudência de Ícaro.

O Labirinto, construiu-o Dédalo cheio de erro, devido às suas pérfidas sinuosidades. Quais as curvas do rio Meandro que, no seu ambíguo curso, ora avança, ora se desvia, ora volta para a nascente, em constantes curvas, assim Dédalo encheu o edifício de inúmeros caminhos e desvios enganosos, com comunicações sem conta (vv. 152-168).

Embora não aborde especificamente o assunto e só lhe faça alusões, não posso deixar de fazer uma breve referência ao Satyricon de Petrónio que já tem sido estudado sob a perspectiva do labirinto. E com esta obra estamos em meados do século I da nossa era. O protagonista, experiente já de longas errâncias, encontra-se, com os seus amigos em casa de Trimalquião, liberto novo-rico. E esse poder económico dá-lhe a superioridade de se julgar que tudo sabe e tudo pode fazer e dizer. A casa de Trimalquião, depois de aventuras e baldões, parecera-lhes um oásis, mas em breve revelou a sua verdadeira natureza, cada vez mais complexa, como a do seu dono. Envolvidos em intermináveis peripécias, dela tentam fugir várias vezes, mas sem conseguirem: sempre uma porta falsa. E o protagonista comenta angustiosamente: «Que vamos fazer, homens míseros que somos e encerrados neste novo labirinto?» (73. 1). Por fim obtêm êxito. Mas, uma vez fora da casa, são obrigados a vaguear sendas desconhecidas e pedregosas. Às apalpadelas e guiados pelas raras referências retidas, lá conseguem refazer o percurso, através da cidade desconhecida, de retorno à pensão. Não é ainda a liberdade: a porta, fechada, só se abre com a chegada de um criado de Trimalquião que, sem bater, a empurra e entra.

Mas mal acabavam de sair desse labirinto, logo se introduzem em outro, ao embarcarem no navio de Lica. Ou seja, a vida humana, cheia de incidências, de perigos, de dificuldades, é um labirinto. Por isso. como observa Nair Castro Soares, o protagonista do Satyricon, perdido num mundo onde a luz era rara e as insídias e as surpresas espreitavam em todas as esquinas, lamentava-se que «nem sequer tínhamos um archote de refúgio, que abrisse caminhos aos pobres vagueantes» $(79.1)^{34}$.

E assim de edifício complexo, construído pelo engenho do homem para aí encerrar aquilo que de vergonhoso e infamante foi gerado, o labirinto evoluiu metaforicamente para o pensamento humano nas suas buscas sempre infrutíferas, para a cidade em que os homens se vêem perdidos e desconhecidos no meio dos outros, para a vida humana num mundo tão hostil. A libertação consegue-se pela coragem, mas também pela doação e pela ajuda. Teseu é o herói da coragem, da doação, da liberdade. Mas, sozinho, sem o contributo de Ariadne, não teria levado a empresa a cabo. Assim o compreendeu José Augusto Seabra neste belo 
poema de Gramática Grega, em que Teseu aparece como «escravo da liberdade e do destino»:

\author{
Como circulas \\ no labirinto \\ de fuga em fuga \\ cercando Minos \\ duma loucura \\ que te domina \\ mais do que o Touro \\ em que ruminas, \\ Teseu, - escravo \\ da liberdade \\ e do destino, \\ ainda errando \\ com Ariadna \\ de signo em signo?
}

\title{
NOTAS
}

Segundo algumas versões o desagrado seria de Afrodite.

${ }^{2}$ Embora seja essa a sua representação mais usual, outras surgem na arte figurativa: corpo de quadrúpede e cabeça de homem, corpo de homem e cabeça de leão, cavalo, carneiro e mesmo de homem. Vide S. Woodford, in LIMCA VI, s. v. «Minotauros», n. ${ }^{\circ}$ 6, 6a, 7, 12, 13, 15, $25 \mathrm{e}$ 33 e com. p. 579.

${ }^{3}$ Sobre a composição dos Poemas Homéricos e sua historicidade vide José Ribeiro Ferreira, Hélade e Helenos. 1-Génese e evolução de um conceito (Coimbra, ${ }^{2}$ 1992), p. 39-66.

${ }^{4}$ Tradução de M. H. Rocha Pereira, Hélade (Coimbra ${ }^{6} 1995$ ), p. 37.

5 Vide Wilamowitz, Homeridche Untersuchungen (Berlin, 1884), p. 149; A. Heubeck e A. Hoekstra, A commentary on Homer's Odyssey (Oxford, 1989), ad 11. 321-325.

- Outra versão justifica que Teseu, atirado por uma tempestade para Chipre, aí a tenha deixado pelo facto de ela se encontrar grávida e não aguentar a viagem. Quando mais tarde à ilha regressa para a levar, Ariadne tinha morrido de parto (Plutarco, Teseu 20. 3-6). Vide The Oxforf Classical Dictionar, s. v. "Theseus" e "Ariadne".

7 The Secret of Crete (1975).

${ }^{8}$ Vide S. Hood, A pátria dos heróis (trad. port., Lisboa, 1969), p. 97-101. O livro de Castledeu a que me refiro é The Knossos Labyrinth. A new of the Palace of Minos at Knossos (1990). A conferência de M. H. Rocha Pereira, está publicada em Conimbriga, 32-33 (1993-1994), p. 57-74. 
${ }^{9}$ S. Hood, A pátria dos heróis (trad. port., Lisboa, 1969), p. 90.

${ }^{10}$ Embora haja quem admita que a causa desses destruições terá sido a invasão de Lúvios provenientes da Anatólia, é mais provável que tenham sido destruídos por abalos sísmicos ou por guerras internas. Vide S. Hood, A pátria dos heróis (trad. port., Lisboa, 1969), p. 89.

11 Vide S. Hood, A pátria dos heróis (trad. port., Lisboa, 1969), p. 89-92.

12 S. Hood, A pátria dos heróis (trad. port., Lisboa, 1969), p. 59-60.

13 S. Hood, Os Minóicos (trad. port., Lisboa, 1973), p. 17.

14 Vide S. Hood, A pátria dos heróis (trad. port., Lisboa, 1969), p. 82-83.

15 Vide S. Hood, A pátria dos heróis trad. port., Lisboa, 1969), p. 94, texto a figs. 70-73.

${ }^{16}$ Chantraine, autor do mais recente dicionário etimológico do grego (1980), dá as diversas hipóteses e não toma posição.

${ }^{17}$ Sobre o tema de Teseu no referido Catálogo vide M. L. West, The Hesiodic catalogue of women. Its nature, structure and origines (Oxford, 1985), pp. 107-108.

18 Vide A. Lesky, Historia de la literatura griega (trad. esp. Madrid, 1968), p. 105-106; A. Barnabé, «La épica posterior», in J. A. López Férez (ed.), História de la literatura griega (Madrid, 1988), p. 90.

${ }^{19}$ Dado tratar-se de uma exaltação da Simaquia de Delos, fundada em 477 a. C., a maioria dos estudiosos datam-no dos primeiros anos da existência dessa aliança. Vide Bacchylide. Dithyrambes - Épinices - Fragments. Texte établi par J. Irigoin et traduit par J. Duchemin et L. Bardollet (Paris, 1993), p: 21-22. A data de 470 a. C. é precisamente a proposta por R. Jebb, Bacchylides, The poems and fragments (Cambridge, 1905), p. 229. Mas já D. A. Schmidt, «Bacchylides 17 - Paean or dithyramb?», Hermes 118 (1990) 18-31, o considera posterior a 469 a.C.

${ }^{20}$ Um tratamento mais desenvolvido do mito de Teseu na poesia da época arcaica e clássica pode ser consultado em A. Barnabé, «El mito de Teseo en la poesía arcaica e clásica», in $\mathbf{R}$. Olmos (ed.), Coloquio sobre Teseo y la copa de Aison (Madrid, 1992), p. 97-118.

21 Vide, para os Cretenses, Cantarela 13-16; C. Austin, Nova Fragmnenta Euripidea (1968) 49-58; para o Teseu, Webster, The Tragedies of Euripides (London, 1967), p. 87-92.

22 R. Burger, The Phaedo. A Platonic Labyrinth (New Haven, 1984). Recensão na Humanitas 37-38 (1986), 332-336.

${ }^{23}$ Vide A. Kauffmann-Samaras, «Thesée et le Minotaure: Mythe et realité à travers la céramique grecque», in R. Olmos (ed.), Coloquio sobre Teseo y la copa de Aison (Madrid, 1992), p. 155-167.

${ }^{24}$ Cerca de 650 a. C. Vide W. A. Daszewwski, in LIMCA III, s. v. "Ariadne», n. ${ }^{37}$, p. 1055; S. Woodford, in LIMCA VI, s. v. «Minotauros», n. ${ }^{\circ} 16$, p. 575.

${ }_{25}$ Ânfora em relevos de c. 670-660 a. C. Vide W. A. Daszewwski, in LIMCA III, s. v. «Ariadne» n. ${ }^{\circ}$ 36, p. 1055.

26 Vide W. A. Daszewwski, in LIMCA III, s. v. «Ariadne», p. 1066.

${ }^{27}$ E. g. Skyphos beócio, Museu do Louvre MNC 675; CVA 17, pl. 29 (1152) 1-4; LIMCA III, s. v. «Ariadne», p. 1055.

28 Vide W. A. Daszewwski, in LIMCA III, s. v. "Ariadne», p. 1066.

29 Vide F. Brommer, Theseus. Die Taten (Darmstadt, 1982), pp. 35-64; E. R. Young, The Slaying of Minotaur: Evidence, in Ricardo Olmos (ed.), Coloquio sobre Teseo y la copa de Aison (Madrid, 1992), p. 156, nota 11.

30 «El mito de Teseo en la poesía arcaica e clásica», in R. Olmos (ed.), Coloquio sobre Teseo y la copa de Aison (Madrid, 1992), p. 115-117.

${ }^{31}$ S. Woodford, in LIMCA VI, s. v. «Minotauros», p. 581.

${ }^{32}$ S. Woodford, in LIMCA VI, s. v. "Minotauros», n. ${ }^{\circ} 4$, p. 575.

33 Sobre este carme vide K. Quinn, Catullus. An interpretation (London, 1972), p. 261-264; Ch. Martin, Catullus (New Haven - London, 1992), p. 151-171 e 174-175.

34 "A literatura de sentenças no Humanismo português: res et verba", in Humanismo Portugês na época dos Descobrimentos, Actas (Coimbra, 1993), p. 410. Sobre o labirinto no Saty- 
rikon de Petrónio, vide P. Fedeli, «ll tema del labirinto nel Satyricon di Petrónios», in Atti del convegno Internazionale "Letteratura classiche e narratologia». Materiali e contributi per la storia della narrativa greco-latina (Perugia, 1981), p. 161-174. 